\title{
Land Tenure Conflicts After the End of Use Rights for Plantation Legal Entities in Indonesia
}

\author{
Alpi Sahari \\ Universitas Muhammadiyah Sumatera Utara, Indonesia \\ alpisahri@umsu.ac.id
}

\begin{abstract}
Land problems almost occur throughout Indonesia, without exception in Medan, North Sumatra Province. In Medan there is PTPN II land which, due to community needs, the government chose not to extend the HGU (Hak Guna Usaha) for the benefit of the community. The government considers that the people need this land more in order to meet the needs of life and the welfare of the entire community. The method used in this paper is juridical normative by adopting a legal synchronization approach, both vertically and horizontally, on land tenure conflicts after the expiration of the Legal Entity for Plantation Companies in Indonesia. Data obtained through literature search. The results show that the provisions regarding land tenure have been regulated in Law number 5 of 1960 concerning Basic Agrarian Principles or often referred to as UUPA. In article 16 paragraph 1 of Law Number 5 of 1960 UUPA, it is stated that land rights include ownership rights, land use rights, building use rights, usage rights, lease rights, land opening rights, rights to collect forest products, other rights that are not included in the rights mentioned above which will be stipulated by law as well as rights which are temporary as mentioned in Article 53 of Law Number 5 concerning UUPA. The existence of land rights that have been regulated in law often creates confusion and overlaps in the control of the land object. There is still a lack of and low understanding of the law by the majority of the community, are often used by irresponsible individuals with the intention of obtaining benefits in the form of land rights through control of the land. Then the role of the government has not run optimally in protecting the rights of land controlled by the community. The government has not been able to collect data and make complete registrations of land tenure in Indonesia. This is the cause of the frequent occurrence of land tenure conflicts so that the participation of all levels of society as well as the government is urgently needed.
\end{abstract}

\author{
Keywords \\ rights land tenure \\ conflict; plantation \\ legal entity business \\ use; Indonesia
}

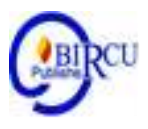

\section{Introduction}

The interpretation of the UUPA is a source of dispute that arises because several articles in the form of the contents of the law are declared unable to resolve the problems that arise, for example the understanding of the community currently occupying the exs HGU land of PTPN and the plantation company holding the HGU. In general, the problems that arise are often grouped by experts into four groups, namely: First, which is directly or indirectly related to the social function of land rights. Second, regarding the arrangement of land tenure or restructuring of land ownership / control. Third, regarding land stewardship, including the obligation to maintain the land. Fourth, regarding land rights and regarding legal certainty of land rights. 
Land disputes and conflicts are complex and multidimensional problems. Therefore, efforts to prevent, handle and resolve must take into account various aspects, both legal and non-legal. Often the handling and resolution of land disputes and conflicts is faced with dilemmas between different interests that are equally important. Finding a balance or win-win solution for conflicts that already occur clearly requires effort that is not easy. Legislation that applies to land acquisition does not accommodate the paradigm of community development that is just, prosperous, and prosperous. The discrepancies between the forms of policy regulation often lead to disputes or conflicts. (Isnaini et al, 2020)

Good land data and information management has an important role in realizing the goal of sustainable national development. This activity is an important part of realizing good governance (good governance). Good governance is one of the pillars supporting sustainable development, in addition to economic, environmental and social (Williamson, I., Enemark, S., Wallace, J. \& A., 2010), so that in the management of data and information in the good land sector will support the realization of the goal of sustainable national development. (Sriono, et al. 2021)

In addition, the central government in the formulation of policies does not extend Business Use Rights for Plantation Legal Entities which only states the area of land issued and the amount of land in each region without mentioning the location (village, subdistrict, let alone potok - potok tanah which makes it easier identification of the existence of the land). This condition provides space for certain individuals to take part in seizing the land for the former PTPN II HGU for personal gain. While the second factor is in the form of its distribution, where there are still many questions that must be answered, namely: who will be the subject (direct beneficiary of the distribution of land), in what way will this redistribution of land be carried out and what form of rights will arise over these lands, as well as the status of land that has been transferred to another party, either as ownership or lease rights. Management of ex-HGU land by the government that is not in accordance with these provisions creates many problems that lead to land tenure conflicts.

Furthermore, most of the land tenure conflicts occurred in the location of the former PTPN HGU land area (which had been used up but not extended), which was occupied by tenants as one of the sources of conflict. In addition, the Van Consessie Deed was signed by Sultan Maimon Al Rasyid Perkasa Alam and Deli Cultur Maatschaappij Administrator JGA Godenhart and approved by Resident der Outkust Van Sumatera PJ Kooreman. which is used by the community as the basis for land control over the former PTPN II HGU. Some of the conflicts referred to so far have not been completely resolved to the root of the problem, and have even lasted for years. This is where the importance of optimizing crosssectoral synergy between PTPN, Medan City Government, Deli Serdang Regency Government, BPN, tenant groups and other stakeholders so that land tenure conflicts can be resolved through the formulation of appropriate legal policies.

\section{Review of Literature}

\subsection{Source of Land Tenure Conflict after the Expiration of Business Use Rights}

The granting of concessions to plantation entrepreneurs occurred during the sultanate and colonial times, followed by the modification of concession rights to erfacht rights. This condition was also continued during the independence era, where the land was concessions and erfacht rights which is given to plantations which expire are modified to become Business Use Rights (HGU). In these three periods, land disputes are still ongoing between the plantation entrepreneurs and the watchmen and the tenant communities. Especially if it 
is related to the granting of erfacht rights during the colonial period which violated land rights according to customary law, it was a source of conflict in the land sector, because the colonial government did not recognize rights according to customary law, especially after the application of the Domein Verklaring principle, namely the state became the owner ( eigenaar), unless people can prove that they have eigendom rights over the land.

In addition to the matters described in terms of PTPN's ex-HGU land, the land issue is also related to several factors which are interrelated so that it worsens the situation and makes it difficult for a comprehensive and complete resolution to always be guided by the principles of justice, certainty and benefit. Based on the analysis of the data and information obtained, at least there are several factors that are the source of the current problems, namely the status / condition of the land, legal basis and other implementing regulations, coordination between related agencies and parties controlling and demanding land in the HGU plantation area. as follows:

\subsection{Indigenous peoples}

a. There are people who think that PTPN II has forcibly confiscated their land even though they have evidence / basis of rights in the form of concessions.

b. There are people who demand that their customary land which has been confiscated by the plantations so far, to be returned to the customary association and then they will control the distribution and use of the land.

\subsection{The Prosecution Society}

a. There were community claimants who claimed that the land belonged to them which was obtained initially through forest clearing activities for cultivation around 19461953, but in 1967 the land was forcibly confiscated by the plantation.

b. There is a community of prosecutors who hold various documents (in the form of photocopies) such as KTPPTP, SKPT-SL, Landreform SIM, Regent Decree and other certificates.

\subsection{Community cultivators / occupying land}

1. There are community groups who cultivate / cultivate ex-PTPN HGU land, which they work on daily as a forging of crops for various types of crops (such as maize, cassava, banana, etc.).

2. There are community groups / tenants who control the land ex-PTPN HGU, but it needs to be examined more deeply whether they are pure cultivators or are a group of people who are used by certain individuals to be able to control the land under wraps. This is one of the modes of practice of the land mafia.

As for land problems as described above, especially the management of plantation businesses in plantation businesses provided to BUMN, for example PTPN II, which most of the HGU is located in the North Sumatra region, namely PT. Perkebunan Nusantara II which is located in North Sumatra originates from the land concession of NV. Van Deli Maatschappiy, which began to be cultivated in 1870, has an area of 250,000 ha which stretches from the Snake River in Deli Serdang Regency to Sei Wampu in Langkat Regency. In 2002 through the Central BPN Decree No, 42, 43, and 44 / HGU / BPN / 2002 dated 29 November 2002, the Government no longer issued an extension of the PTPN II HGU application covering an area of 5,873,068 ha due to community demands based on the SKPT- SL and KTPPT. Particularly with the area of 5,873 ha that is no longer in its HGU (ex-HGU) in accordance with BPN Decree No.42.43 and 44 / HGU / BPN / 2002 , it is clearly stated that the plantation lands which are not extended will become land. 
which is directly controlled by the state and hands over the regulation / control, ownership, compression and use of the land to the Governor of North Sumatra Province and subsequently processed according to the provisions and laws in force after obtaining a permit to release assets from the competent Minister in this case the Minister of BUMN RI.

The issuance of 5,873.068 ha of land from the PTPN II (Ex HGU) HGU in fact did not become a new milestone for the resolution of agrarian conflicts in North Sumatra, especially those related to PTPN II, but on the contrary became the beginning of the expansion of conflicts and land problems. The factors that influence the emergence of the expansion of the conflict and land problems, namely first in the case that the release of land covering an area of 5,873.068 ha from the PTPN II HGU is not accompanied by a map of land position in the Central BPN Decree No, 42, 43, and 44 / HGU / BPN. / 2002. In addition, there are other problems that cause land conflicts over the former PTPN II HGU land, namely:

\subsection{The Extended Hgu Area and Has Issued Certificate Is 11,842.09 Ha and Has} Been Charactered By the Community

1) Community cultivated areas covering an area of 4,446.37 hectares and 7,020.91 hectares can be maintained. For the community cultivated area covering an area of 4,446.37 hectares which is factually included in the plan for the City of Deli Megapolitan in accordance with the Presidential Election No. 62 of 2011 concerning the Urban Spatial Plan for Medan, Binjai, Deli Serdang and Karo (Mebidangro) and for the community cultivated area of 7,020.91 Ha can be taken back because based on the physical conditions in the field it is possible to be planted and is a new work that can still be cleaned.

2) The community cultivated area covering an area of 610.28 hectares which has become a village physically and is continuously controlled by the community can be transferred by way of selling through a direct appointment mechanism to the community (compact village) by consulting with the Ministry of BUMN if it meets the elements of "certain conditions" as referred to referred to in Article 9 letter c Regulation of the Minister of BUMN No. PER-02 / MBU / 2010 and asked for an official stipulation from the local government that it was true that the area had become a compact village.

\section{Results and Discussion}

\subsection{The Area Has Not Been Issued HGU Certificate Area OF 2,915, 23 Ha}

1) An area of 2,386, $69 \mathrm{Ha}$ which has been legally extended in accordance with BPN Decree No. 42, 43 of 2002 and factually including productive land can be followed up for the certificate issuance process.

2) The area of 506.43 hectares is factually excluded from productive areas and is physically not controlled and an area of 22.11 hectares is factually controlled by the Medan Campus LPP, PTPN II (Persero) as the owner of the HGU can carry out the transfer through a sales or exchange mechanism swap.

\subsection{Divestment Area and Loan to Use}

1) The divestment area covering an area of 1,246.64 hectares and a lease-to-use area of 21.10 hectares can be followed up by write-offs and breaking up the indul / origin certificate.

2) That the lease-to-use area of $21.10 \mathrm{Ha}$ can be transferred to the regional government, by ensuring that if the transfer is intended to carry out the duties and functions of the state / 
government, the transfer is through a direct appointment mechanism and for the public interest through a compensation mechanism.

\subsection{Unextended HGU}

Other land issues of the former PTPN II HGU that have led to land tenure conflicts are the Decree of the Minister of State-Owned Enterprises of the Republic of Indonesia Number: S-567 / Mbu / 09/2014 dated September 30, 2014 concerning the Resolution of Problems with the HGU land area being extended to an area of 56,341.85 5,873.06 Ha and Unextended HGU Land which is based on JAMDATUN's Legal Opinion, in essence decides as follows:

1. Issuance of certificates for extended HGUs and proposals to issue new HGUs for retained land (from HGUs that are not renewed)

2. Transfer by sale or compensation. Sales by public offer / limited offer / direct appointment (in terms of meeting the requirements of certain conditions).

3. Administrative write-off for land that has been previously divested.

Decree of the Minister of State-Owned Enterprises of the Republic of Indonesia Number: S-567 / Mbu / 09/2014 dated September 30, 2014, if analyzed based on statutory regulations in the land sector, is not very basic, even contradicts the statutory regulations. This can be described as follows:

a. Issuance of certificates for extended HGUs and proposals to issue new HGUs for retained land (from non-renewed HGUs). The decision of the Minister of BUMN is very contradictory and does not comply with the authority of BPN given by the State based on statutory regulations in the land sector to regulate and grant land rights and obligations that must be obeyed by land rights holders (Law Number 5 of 1960 , Government Regulation Number 40 of 1996, Government Regulation Number 24 of 1997, Government Regulation Number 46 of 2002, Presidential Decree Number 10 of 2001, Presidential Decree Number 103 Jo. Number 3 of 2002, Presidential Decree Number 110 of 2001 Jo. Number 5 Year 2002, Presidential Decree Number 309 Year 2001, Regulation of the State Minister for Agrarian Affairs / Head of BPN Number 3 Year 1997, Regulation of the Minister of Agrarian Affairs / Head of BPN Number 3 of 1999, Regulation of the Minister of Agrarian Affairs / Head of BPN Number 9 of 1999, Decree of the Head of BPN Number 6 of 2001, Decree of the Head of BPN Number 12 of 2001). Regarding the extension and non-renewal of the PTPN II HGU, it has been decided based on the Decree of the Head of the National Land Agency, among others: First, the Decree of the Head of the National Land Agency Number: 42 / HGU / BPN / 2002 concerning the Granting of Extension of Business Use Rights for Land located in Deli Regency Serdang, North Sumatra Province, with an extended HGU area of 14,503,1100 hectares and a non-extended HGU covering 3,353,5900 hectares. Second, the Decree of the Head of the National Land Agency Number: 43 / HGU / BPN / 2002 concerning the Granting of Extension of Business Use Rights for Land located in Langkat Regency, North Sumatra Province with an extended HGU area of 1,866.8600 $\mathrm{Ha}$ and a non-extended HGU covering an area of 1,210.8680 Ha. Third, the Decree of the Head of the National Land Agency Number: 44 / HGU / BPN / 2002 concerning the Granting of Extension of the Use of Right to Land for Land located in Binjai City, North Sumatra Province, whose decision states reject the request for extension of the PTPN II HGU period of 238.52. Ha.

b. The decision of the head of BPN regarding HGU which was not granted an extension in his decision dictum stated that the land in question was directly controlled by the State and handed over the control, ownership, utilization and use of the land to the Governor 
of North Sumatra for further processing in accordance with the provisions of the applicable laws after obtaining a permit to release the assets. from the competent Minister. This is of course the SOE Minister's decision stating that the proposed issuance of a new HGU for defended land (from a non-renewed HGU) is very contradictory to the decision of the Head of BPN so that it can be said that it has no binding legal force and violates land administration rules

c. It is also necessary to add based on Article 34 of the UUPA and Article 17 of Government Regulation Number 40 of 1996, among others, it is stated that one of the reasons for the abolition of the $\mathrm{HGU}$ is due to the expiration of the period as stipulated in the decision to grant or extend it. The abolition of the HGU according to Article 17 paragraph (2) PP No. 40 of 1996 resulted in the land becoming land directly controlled by the State. Furthermore, Article 12 paragraph 1 letter g and h PP Number 40 Year 1996 states that the former right holder is obliged to return the land granted with the HGU to the State after the HGU has been abolished and submit the revoked HGU certificate to the Land Office.

Decree of the Minister of BUMN which states "Transfer is by way of sale or compensation. Sales by public offering / limited offer / direct appointment (in terms of meeting certain conditions) of land for which the HGU has been extended or the HGU which is not extended is very baseless and contrary to statutory regulations and does not comply with the Decree of the Head of BPN in particular. against HGU that is not renewed. With respect to an extended HGU based on statutory regulations, PTPN II is not entitled to carry out an act of transfer by means of a sale or compensation. Sales by public offer / limited offer / direct appointment because PTPN II is the recipient and holder of land rights in the form of HGU not the owner of the land (in the concept of controlling rights by the State) so that it does not have the authority to transfer land that is not in accordance with its designation. In accordance with the legal rule in the land sector, that HGU which is not used in accordance with its designation, the HGU can be canceled so that the consequences based on Article 17 paragraph (2) PP Number 40 of 1996 for the abolition of HGU result in the land becoming land directly controlled by the State.

\subsection{Obstacles in Handling Conflict of Land Tenure after the termination of Plantation Legal Entity Business Use Rights}

One of the obstacles in handling land tenure conflicts comes from the substance of the law which includes the material of the legislation governing the ex-PTPN II HGU issues. The legal substance is the rules, norms and patterns of real human behavior in the system. The substance of the law also means the products produced by people who are in the legal system, both in the form of decisions they issue, as well as new rules that they draft. The most prominent obstacle concerns inconsistent laws and regulations that affect the implementation of law enforcement against criminal acts originating from the ex-PTPN II HGU conflict committed by the Police. These obstacles include:

1. Lack of firmness in existing laws and regulations, because there are still several overlapping laws and regulations, resulting in different interpretations of the law. This is related to the authority between agencies related to the issue of the former PTPN II HGU. For example, each agency has the right to determine the status of the former PTPN II HGU land. The unclear division of authority will create a conflict of interest. The basis for this authority is the issuance of the Letter of the Minister for State-Owned Enterprises of the Republic of Indonesia Number: S-567 / MBU / 09/2014 dated September 30, 2014. Subject: Resolution of the issue of HGU land area extended to an area of 56,341.85 hectares and non-extended HGU land covering an area of 5,873,06 
$\mathrm{Ha}$ and assets in the form of official housing buildings owned by PT Perkebunan Nusantara II (Persero).

2. Letter of the Minister of State-Owned Enterprises of the Republic of Indonesia Number: S-567 / MBU / 09/2014 dated September 30, 2014. In practice, sometimes clashing in the handling of the former PTPN II HGU, which has implications for the National Police's actions to overcome legal problems arising from the conflict. In addition, there is no clear division of authority in resolving the status of the former PTPN II HGU land, which allows conflicts of interest between entities in the field.

Another obstacle is related to the legal structure which can be interpreted, namely obstacles relating to the formal legal aspects on which the authority is given as well as the operation procedures of all authorized agencies related to the ex PTPN II HGU issues. The legal structure can be said to be an institution that carries out authority with all the processes that take place in it. This is evidenced by the absence of a common perception regarding the resolution of the former PTPN II HGU problem. The land handlers were impressed by the sectoral ego of each agency. Each agency equally has the same authority, hence the overlapping authority and policies of each agency. Each agency seems to work independently. In its application, the cooperation forum at the central level has not run optimally and comprehensively to all stakeholders in the field. To make matters worse, sometimes there is friction / minor incidents or a conflict of human interest.

\section{Conclusion}

Land tenure conflicts besides having serious impacts both politically, economically and socio-culture, also have implications for increasing social security disturbances so that some communities are disturbed and unable to carry out their activities. In addition, land conflicts have also disrupted the ongoing development process in the area, because it is not uncommon for people in conflict to carry out demonstrations by blocking roads, blocking government offices and other strategic places, and even acting anarchically to seek justice for justice. land problems faced.

\section{References}

Barda Nawawi Arief. (2011). Kebijakan Hukum Pidana (Perkembangan Penyusunan Konsep KUHP Baru), Kencana Prenada Media Grup, Jakarta.

Buku Panduan Penanganan Permasalahan Pertanahanan Eks HGU PTPN II, Pemerintah Propinsi Sumatera Utara, 2015

http://www.bumn.go.id/ptpn2/berita/48/Sejarah.dan.Perkembangan.Lahan.PTPN.II

Isnaini, et al. (2020). The Models of North Sumatra Provincial Government Policy in Resolving the Ex-Hgu Land Conflicts of PTPN II Plantations in Deli Serdang Regency. Budapest International Research and Critics Institute-Journal (BIRCIJournal). P. 1206-1215.

Muhammad Bakri,et al, Penyelesaian Sengketa Pemakaian Tanah Perkebunan Tanpa Izin yang Berhak atau Kuasanya, Studi Kasus Daerah Jawa Timur, Malang, Universitas Brawijaya

M. Yamin. (2003). Beberapa Dimensi Filosofis Hukum Agraria, Pustaka Bangsa Press, Medan

Sriono, et al. (2021). Legality of Execution of Collateral Based on Electronic Mortgage Certificate in Bank Credit Agreement. Budapest International Research and Critics Institute-Journal (BIRCI-Journal). P. 15-27 
Syafruddin Kalo, Masyarakat dan Perkebunan: Studi Mengenai Sengketa Pertanahan Antara Masyarakat Versus PTPN-II dan PTPN-III Di Sumatera Utara, Program Pascasarjana Universitas Sumatera Utara 